\title{
A cross sectional study of contact dermatitis among chicken farmers
}

\author{
Tika Nela Sirait ${ }^{*}$, Helen Kartika Hasianna Sinaga ${ }^{2}$ \\ ${ }^{1}$ Bagian Kesehatan dan Keselamatan Kerja, Universitas Prima Indonesia, Medan \\ ${ }^{2}$ Bagian Administrasi Kebijakan Kesehatan, Universitas Prima Indonesia, Medan
}

DOI: 10.24252/al-sihah.v12i2.16010

Received: 18 September 2020 / In Reviewed: 19 September 2020 / Accepted: 25 September 2020 / Available online: 29 September 2020 (C) The Authors 2020. This is an open access article under the CC BY-NC-SA 4.0 license

\begin{abstract}
Occupational diseases can be caused by several factors of work and environmental conditions of workers. Poor environmental conditions and worker behavior are some of the triggers for the emergence of dermatitis in workers. Contact dermatitis in chicken farm workers can be caused by exposure to chemicals from animal feed. The purpose of this study was to determine the factors that influence the occurrence of dermatitis in chicken farmworkers. This research is a quantitative study with a cross-sectional design. The population in this study was a total sample of 35 people. The results showed that there was no relationship between the use of personal protective equipment, working period, and personal hygiene with the appearance of symptoms of dermatitis in workers. However, this study found that workers who have worked for more than 12 months and practice good personal hygiene tend to avoid symptoms of dermatitis. This study provides a recommendation that the longer a person has worked, personal hygiene improvement needs to be done to avoid dermatitis.
\end{abstract}

Keywords: dermatitis; personal hygiene; personal protective equipment; work periods

\begin{abstract}
ABSTRAK
Penyakit akibat kerja dapat disebabkan oleh beberapa faktor pekerjaan dan kondisi lingkungan pekerja. Kondisi lingkungan yang buruk dan perilaku pekerja menjadi salah satu pemicu timbulnya penyakit dermatitis pada para pekerja. Dermatitis kontak pada pekerja ternak ayam dapat diakibatkan oleh paparan bahan kimia dari pakan ternak. Tujuan penelitian ini dilakukan ialah untuk mengetahui faktor-faktor yang mempengaruhi terjadinya penyakit dermatitis pada pekerja ternak ayam. Penelitian ini merupakan studi kuantitatif dengan rancangan crosssectional. Populasi dalam penelitian ini adalah total sampel sebanyak 35 orang. Hasil penelitian menunjukkan bahwa tidak ditemukan hubungan antara penggunaan alat pelindung diri, masa kerja, dan personal hygiene pekerja dengan timbulnya gejala dermatitis pada pekerja. Namun penelitian ini menemukan bahwa pekerja yang memiliki masa kerja di atas 12 bulan serta melakukan personal hygiene dengan baik maka akan cenderung terhindar dari gejala penyakit dermatitis. Penelitian ini memberikan rekomendasi bahwa semakin lama masa kerja dilalui seseorang maka peningkatan personal hygiene perlu dilakukan untuk menghindari terjadinya penyakit dermatitis.
\end{abstract}

Kata kunci : dermatitis; higiene perorangan; masa kerja; alat pelindung diri

*Alamat Korespondensi:

Girsang 1 No. 72, Kel. Girsang, Kab. Simalungun, Sumatera Utara

Email: tikanelasirait95@gmail.com
ISSN-P : 2086-2040

ISSN-E : $2548-5334$

Volume 12, Nomor 2, Juli-Desember 2020 


\section{PENDAHULUAN}

Timbulnya penyakit dan gangguan kesehatan masyarakat dapat diakibatkan oleh beberapa faktor risiko yang timbul dalam lingkungan kerja. Keberadaan penyakit di tempat kerja masih bersifat multifaktor yang dapat diakibatkan oleh masalah karakteristik pekerja (Peiser et al., 2012), riwayat kontak (Thetkathuek et al., 2020), faktor lingkungan (Kantor \& Silverberg, 2017) dan higiene pekerja (Ramdan et al., 2018). Dermatitis akibat kerja merupakan penyakit kerja ke dua yang paling umum terjadi di berbagai negara (Kasemsarn et al., 2016). Dermatitis kontak akibat kerja adalah respons peradangan yang disebabkan oleh kontak dengan sumber iritan atau alergen di lingkungan kerja (Qin \& Lampel, 2015). Selain faktor terkait perilaku pekerja, faktor lingkungan eksternal seperti penanganan bahan kimia (Sharma et al., 2018) dan kondisi kerja basah (Behroozy \& Keegel, 2014), memainkan peran penting dalam perkembangan dermatitis ini.

Prevalensi terjadinya penyakit dermatitis diperkirakan hampir mencapai 230 juta di dunia, sedangkan di negara-negara Asia, prevalensi kejadian dermatitis atopik telah meningkat selama beberapa dekade terakhir (Tsai et al., 2019). Penyakit dermatitis secara global mempengaruhi 15$20 \%$ anak-anak dan $1-3 \%$ orang dewasa
(Nutten, 2015). Di Eropa, mereka berkontribusi terhadap lebih dari 30\% dari semua penyakit akibat kerja yang tercatat (Jakasa et al., 2018). Namun, sebagian besar kasus dermatitis tidak didaftarkan dengan benar sebagai kasus penyakit karena dianggap sebagai masalah kulit ringan dan disepelekan (Nawangsih et al,, 2020). Di Australia dilaporkan kejadian dermatitis kontak 2,15 per 10.000 tenaga kerja per tahun (Lau et al, 2011). Sedangkan di Indonesia penyakit kulit akibat kerja yang sering dialami oleh pekerja adalah dermatitis kontak, yaitu dermatitis yang disebabkan oleh zat atau zat yang menempel pada kulit (Djuanda, 2017). Di indonesia, penyakit dermatitis menempati posisi tertinggi sebagai penyakit yang sering diderita pekerja dengan angka kejadian sekitar 50$60 \%$ dari seluruh penyakit kerja (Ningtyas, 2013).

Kementerian pertanian mencatat bahwa terjadi peningkatan budidaya ayam broiler di Indonesia setiap tahun. Dibanding tahun 2016, populasi ternak unggas secara nasional pada tahun 2017 mengalami pertumbuhan, dengan rincian ayam buras 299,7 juta ekor dengan pertumbuhan 1,82 persen, ayam ras petelur 176,9 juta ekor dengan pertumbuhan 9,65 persen, ayam ras pedaging 1,8 miliar ekor dengan pertumbuhan 13,22 persen. Di Sumatera Utara populasi ayam pedaging pada tahun 
2018 telah mencapai 58.153.185 juta ekor

(Kementerian Pertanian, 2018).

Saat ini prospek pasar pada komoditas unggas sangat baik karena didukung oleh karakteristik produk tersebut yang dapat diterima oleh sebagian besar masyarakat Indonesia, dengan harga relatif terjangkau serta akses memperoleh lebih mudah. Para peternak ayam menjadi kontributor utama penyedia protein hewani nasional (Susilo, 2020). Namun pemeliharaan unggas dapat berdampak pada kesehatan masyarakat termasuk penyakit menular yang diperoleh dari praktik pemeliharaan atau konsumsi telur, pengelolaan limbah yang tidak tepat, interaksi dengan hama serta faktor gangguan seperti kebisingan, dan bau (Pullock et al., 2012). Peternakan ayam belakangan menjadi sumber terjadinya berbagai penyakit seperti dermatitis. Implikasi sosio-ekonomi dari penyakit dermatitis sangat signifikan dan kemungkinan dapat berdampak pada kualitas kerja (Kalboussi et al., 2019), psikososial (Marron et al., 2020) dan konsekuensi finansial tambahan sebagai akibat dari penurunan kualitas hidup (Diepgen, 2012).

Berdasarkan survei awal yang dilakukan dari pekerja ternak ayam yang terletak di Kecamatan Pancur Batu dan hasil wawancara singkat pada pekerja menunjukkan bahwa lingkungan kerja, personal hygiene pekerja serta kepatuhan pekerja dalam menggunakan APD, semakin memperkuat landasan bahwa pekerja sangat rentan mengalami dermatitis kontak. Berdasarkan paparan tersebut, jumlah pekerja yang bekerja di peternakan ayam tersebut berjumlah 35 orang. Seluruh pekerja tidak memiliki asuransi hanya saja jika pekerja sakit maka bekerja akan berobat ke puskesmas terdekat dengan biaya sendiri. Dari data dan permasalahan tersebut penelitian ini bertujuan untuk mengetahui faktorfaktor yang mempengaruhi terjadinya penyakit dermatitis pada pekerja ternak ayam.

\section{METODE PENELITIAN}

Penelitian ini merupakan penelitian kuantitatif observasional dengan rancangan cross sectional. Penelitian ini dilakukan di peternakan ayam pedaging di Kecamatan Pancur Batu Kabupaten Deli Serdang Medan Sumatera Utara Tahun 2020. Penelitian ini dilakukan di bulan Juni 2020. Pemilihan lokasi didasarkan pada pertimbangan. Adanya keluhan kesehatan kulit pada pekerja ternak ayam pedaging serta kedekatan jarak tempat tinggal pekerja ternak ayam bersamaan dengan kandang ayam pedaging yang merupakan tempat kerja yang berpotensi untuk timbulnya keluhan kesehatan kulit.

Perternakan ayam yang peneliti teliti adalah peternakan ayam yang bergerak pada produksi unggas pedaging. Peternakan 
ini telah dikelola selama kurang lebih 10 tahun. Ayam yang diternak mulai usia 0-8 minggu dan siap untuk dipasarkan. Terdapat 8 blok ternak untuk memproduksi unggas ayam dan setiap blok di peternakan ini terdapat sekitar 15.000 ekor ayam. Kondisi
Salah satu faktornya adalah berkontak dengan bahan baku pakan ternak yang berbentuk tepung, dan cairan yang mengandung bahan kimia dan kandang ayam tersebut lembap karena dikelilingi oleh pohon kepala sawit.

Tabel 1. Distribusi Karakteristik Responden

\begin{tabular}{lcc}
\hline Karakteristik & Jumlah & Persen \\
\hline Gejala Dermatitis & 22 & 62.9 \\
Tidak Ada & 13 & 37.1 \\
Ada & & 65.7 \\
Jenis Kelamin & 23 & 34.3 \\
Laki-Laki & 12 & 45.7 \\
Perempuan & & 40 \\
Usia & 16 & 14.3 \\
$30-39$ Tahun & 14 & 42.9 \\
$40-49$ Tahun & 5 & 57.1 \\
$>49$ Tahun & & 28.6 \\
Masa Kerja & 15 & 71.4 \\
$>1$ tahun & 20 & 28.6 \\
$\leq 1$ tahun & & 71.4 \\
Penggunaan APD & 10 & 25 \\
Lengkap & 25 & \\
Tidak Lengkap & 25 & \\
Personal Hygiene & 10 & \\
Baik & & \\
Tidak Baik & & \\
\hline
\end{tabular}

Sumber: Data Primer, 2020

peternakan yang kurang ideal itu dapat menjadi media penyebaran penyakit dari hewan ke manusia, apalagi pekerjanya menghabiskan waktu di dalam kandang, termasuk tidur dan bertempat tinggal di kandang untuk menjaga ayam. Risiko untuk penyebaran penyakit dari lingkungan dan unggas semakin tinggi karena dekatnya jarak antara kamar tidur dan kandang ayam.
Data primer dikumpulkan dengan melakukan observasi secara langsung di lapangan seperti melakukan wawancara dan memberikan lembar kuesioner kepada responden. Sedangkan data sekunder dikumpulkan di pusat kesehatan masyarakat di daerah setempat berupa data karakteristik pasien penyakit dermatitis. Total populasi di ternak ayam tersebut sebanyak 35 orang. 
Dengan penentuan sampel yang digunakan dalam penelitian total sampling. Analisis data yang digunakan dalam penelitian ini adalah uji chi-square yang merupakan uji komparatif terhadap data penelitian kasus dan faktor risiko. yang memiliki personal hygiene tidak baik dan ada gejala dermatitis kontak yaitu sebesar $37,1 \%$, dan pekerja yang memiliki personal hygiene baik dan tidak ada gejala dermatitis kontak yaitu sebesar $17,1 \%$. Berdasarkan hasil analisa data menggunakan

Tabel 2. Hubungan Personal Hygiene Terhadap Gejala Dermatitis Kontak

\begin{tabular}{|c|c|c|c|c|c|c|}
\hline \multirow{3}{*}{ Personal Hygiene } & \multicolumn{4}{|c|}{ Gejala Dermatitis } & \multirow{3}{*}{ Total } & \multirow{3}{*}{ p-value } \\
\hline & \multicolumn{2}{|c|}{ Tidak Ada } & \multicolumn{2}{|c|}{ Ada } & & \\
\hline & $\mathbf{N}$ & $\%$ & $\mathbf{N}$ & $\%$ & & \\
\hline Baik & 13 & 37 & 4 & 34.3 & 25 & \\
\hline Tidak Baik & 4 & 11.4 & 5 & 17.1 & 10 & 0.396 \\
\hline Total & 17 & 48.6 & 18 & 51.4 & 35 & \\
\hline
\end{tabular}

Sumber: Data Primer, 2020

\section{HASIL PENELITIAN}

Berdasarkan tabel 1, terlihat bahwa mayoritas responden adalah berjenis kelamin laki-laki yaitu sebesar $65.7 \%$ yang kebanyakan berusia 30-39 tahun atau sebesar 45.7\%. Sebagian besar responden yang menjadi sampel dalam penelitian ini tidak lengkap dalam menggunakan APD yaitu sebanyak 25 responden atau 71,4\%. Selain itu pada tabel ini menunjukkan sebagian besar responden dengan personal hygiene yang baik yaitu sebanyak 25 responden atau $71,4 \%$ dan sebagian besar responden memili masa kerja $\leq 1$ tahun yaitu sebanyak 20 orang atau $57.1 \%$.

Berdasarkan analisa data mengenai personal hygiene terhadap gejala dermatitis kontak yang terlihat pada tabel 2 menunjukkan bahwa dari 35 responden, pekerja uji korelasi maka diperoleh nilai $\mathrm{p}=0,396<$ ( $\alpha=0,05)$ yang menunjukkan terdapat hubungan antara personal hygiene terhadap gejala dermatitis kontak.

Berdasarkan analisa data mengenai hubungan masa kerja terhadap gejala dermatitis kontak yang terlihat pada tabel 3 menunjukkan bahwa dari 35 responden, pekerja yang memiliki masa kerja $>5$ bulan dan ada gejala dermatitis kontak yaitu sebanyak $28,6 \%$, dan pekerja yang memiliki masa kerja $\leq 5$ bulan dan tidak mengalami gejala dermatitis kontak yaitu sebanyak 20,0\%. Berdasarkan hasil analisa data dengan menggunakan uji chi-square maka diperoleh nilai $p=1,0>(\alpha=0,05)$ yang berarti tidak terdapat hubungan antara masa kerja terhadap gejala dermatitis kontak. 
Berdasarkan analisa data mengenai penggunaan APD terhadap gejala dermatitis kontak yang terlihat pada tabel 4 menunjukkan bahwa dari 35 responden, pekerja yang menggunakan APD tidak lengkap dan ada gejala dermatitis kontak yaitu sebanyak $31,4 \%$, dan pekerja yang menggunakan APD lengkap dan tidak ada gejala dermati-

\section{PEMBAHASAN}

Masa Kerja terhadap Gejala Dermatitis Kontak

Berdasarkan hasil analisis data yang dilakukan oleh peneliti secara statistik menunjukkan bahwa tidak ada hubungan antara masa kerja terhadap gejala dermatitis kontak. Karena pekerja yang sudah lama bekerja sudah memiliki pengalaman yang

Tabel 3. Hubungan Masa Kerja Terhadap Gejala Dermatitis Kontak

\begin{tabular}{|c|c|c|c|c|c|c|}
\hline \multirow{3}{*}{ Masa Kerja } & \multicolumn{4}{|c|}{ Gejala Dermatitis } & \multirow{3}{*}{ Total } & \multirow{3}{*}{ p-value } \\
\hline & \multicolumn{2}{|c|}{ Tidak Ada } & \multicolumn{2}{|c|}{ Ada } & & \\
\hline & $\mathbf{N}$ & $\%$ & $\mathbf{N}$ & $\%$ & & \\
\hline$>5$ bulan & 10 & 28.6 & 11 & 31.4 & 21 & \\
\hline$\leq 5$ bulan & 7 & 20 & 7 & 20 & 14 & 1 \\
\hline Total & 17 & 48.6 & 18 & 51.4 & 35 & \\
\hline
\end{tabular}

Sumber: Data Primer, 2020

tis kontak yaitu sebanyak 5 responden atau sebesar 14,3\%. Berdasarkan hasil analisa data dengan menggunakan uji chi-square maka diperoleh nilai $\mathrm{p}=0,5 \leq(\alpha=0,05)$ yang berarti terdapat hubungan antara penggunaan APD terhadap gejala dermatitis kontak.

Pada tabel 5 menunjukkan bahwa dari 15 responden dengan masa kerja $>1$ tahun yang dianalisis dengan menggunakan uji chi-square, diperoleh nilai $\mathrm{p}=0,044<$ 0,05 yang berarti terdapat hubungan antara personal hygiene pekerja yang memiliki masa kerja lebih dari 12 bulan dengan timbulnya gejala dermatitis. cukup dalam melakukan pekerjaannya dibandingkan dengan pekerja yang masih baru bekerja. Hasil tersebut merupakan Dalam penelitian ini juga dapat diketahui bahwa pekerja dengan masa kerja $>5$ bulan mengalami dermatitis kontak paling banyak. Penelitian ini menemukan bahwa 10 responden yang bekerja $\leq 5$ bulan 5 diantaranya mengeluhkan adanya gejala dermatitis kontak, 35 responden yang bekerja $>5$ bulan 11 diantaranya mengeluhkan adanya gejala dermatitis kontak. Hal ini menunjukan bahwa semakin lama pekerja berkontak dengan bahan baku pakan ternak maka semakin resistan kulit mereka dengan bahan tersebut sehingga tidak lagi merasa- 
kan gejala dermatitis kontak. Kekebalan tubuh akan terbentuk pada pekerja dengan masa kerja yang lama yang paling banyak berinteraksi dengan gejala dermatitis kontak. Para perkerja menganggap mereka menganggap hal tersebut sudah biasa dan merupakan konsekuensi dari pekerjaan. Meskipun terjadi gejala kelainan kulit yang pengalaman seseorang dalam bekerja dan berinteraksi dengan lingkungan di mana ia bekerja, pengalaman akan semakin tinggi seiring dengan tingginya masa kerjanya. Pekerja yang berkontak dengan bahan iritan secara terus menerus akan memiliki resistensi dan kekebalan dari zat penyebab dermatitis.

Tabel 4. Hubungan Penggunaan APD Terhadap Gejala Dermatitis Kontak

\begin{tabular}{|c|c|c|c|c|c|c|}
\hline \multirow{3}{*}{ Penggunaan APD } & \multicolumn{4}{|c|}{ Gejala Dermatitis } & \multirow{3}{*}{ Total } & \multirow{3}{*}{$p$-value } \\
\hline & \multicolumn{2}{|c|}{ Tidak Ada } & \multicolumn{2}{|c|}{ Ada } & & \\
\hline & $\mathbf{N}$ & $\%$ & $\mathbf{N}$ & $\%$ & & \\
\hline Tidak Lengkap & 11 & 31.4 & 14 & 40 & 25 & \\
\hline Lengkap & 5 & 14.3 & 5 & 14.3 & 10 & 0.5 \\
\hline Total & 16 & 45.7 & 19 & 54.3 & 35 & \\
\hline
\end{tabular}

Sumber: Data Primer, 2020

timbul di kulit mereka. Banyak dari responden dengan masa kerja yang lama namun masih merasakan gejala dermatitis kontak karena mengabaikan aspek keselamatan dan kesehatan kerja seperti penggunaan APD dan adanya riwayat penyakit kulit yang diderita oleh pekerja. Masa kerja responden paling lama yaitu 2 Tahun dan yang paling sedikit adalah 2 bulan. Banyak pekerja yang mengeluhkan gejala dermatitis kontak sering mereka rasakan di awal-awal berkontak dengan bahan baku pakan ternak. Semakin tinggi intensitas dan durasi dalam bekerja maka potensi untuk terpapar bahaya yang ditimbulkan oleh lingkungan kerjanya juga akan semakin tinggi. Masa kerja sangat mempengaruhi
Hasil penelitian ini berbeda dengan penelitian yang dilakukan Pradananingrum et al. (2018), yang menemukan bahwa $85,2 \%$ pengrajin tahu di Semarang bekerja dengan masa kerja $>2$ tahun dan positif terkena dermatitis kontak iritan. Pekerja dengan lama kerja $\leq 2$ tahun dapat menjadi salah satu faktor yang mengindikasikan bahwa pekerja tersebut belum memiliki pengalaman Pada penelitian ini jumlah pekerja dengan masa kerja $>2$ tahun dan mengalami dermatitis kontak iritan lebih lama dari yang berkerja $\leq 2$ tahun yang mengalami dermatitis kontak iritan. Hal tersebut dikarenakan masa kerja yang lama akan lebih memungkinkan mempengaruhi pengalaman seseorang terhadap pekerjaan 
dan lingkungan dimana ia bekerja, semakin lama ia bekerja semakin banyak pengalamannya. Pekerja dengan pengalaman yang cukup akan lebih waspada sehingga potensi terpajan bahan iritan lebih kecil. Tenaga kerja yang mempunyai masa kerja yang telah lama tentunya akan lebih berpengalaman serta terampil dalam bekerja. buktikan bahwa penggunaan sarung tangan dan baju lengan panjang efektif dalam mencegah terjadinya gejala dermatitis kontak karena bagian tubuh yang paling banyak berkontak dengan bahan baku pakan ternak adalah tangan sehingga penggunaan sarung tangan dapat melindungi pekerja dari kontak langsung dari bahan baku pakan ternak.

Tabel 5. Hubungan Personal Hygiene Dengan Masa Kerja >12 Bulan Terhadap Gejala Dermatitis

\begin{tabular}{|c|c|c|c|c|c|c|}
\hline \multirow{3}{*}{ Personal Hygiene } & \multicolumn{4}{|c|}{ Gejala Dermatitis } & \multirow{3}{*}{ Total } & \multirow{3}{*}{ p-value } \\
\hline & \multicolumn{2}{|c|}{ Tidak Ada } & \multicolumn{2}{|c|}{ Ada } & & \\
\hline & $\mathbf{N}$ & $\%$ & $\mathbf{N}$ & $\%$ & & \\
\hline Baik & 6 & 40 & 4 & 26.7 & 10 & \\
\hline Tidak Baik & 0 & 0 & 5 & 33.3 & 5 & 0.044 \\
\hline Total & 6 & 40 & 9 & 60 & 15 & \\
\hline
\end{tabular}

Sumber: Data Primer, 2020

\section{Penggunaan APD terhadap Gejala Derma- titis Kontak}

Berdasarkan hasil penelitian ditemukan bahwa responden yang tidak lengkap dalam menggunakan APD yaitu sebanyak 25 responden dan sebanyak 10 responden lengkap dalam penggunaan APD. Responden yang tidak lengkap menggunakan APD dan mengalami gejala dermatitis kontak yaitu sebanyak 11 responden, pekerja yang menggunakan APD lengkap tetapi mengalami gejala dermatitis kontak yaitu sebanyak 5 responden. Alat pelindung diri yang paling banyak digunakan adalah sarung tangan yaitu 18 responden dan baju lengan panjang yaitu 10 responden, sedangkan penggunaan sepatu boot sebanyak 7 responden. Hal ini mem-
Penggunaan alat pelindung diri memilki pengaruh yang sangat besar terhadap kejadian dermatitis kontak karena APD merupakan alat pelindung dari potensi -potensi bahaya yang ada di tempat kerja salah satunya agar terhindar kontak langsung dengan bahan kimia/bahan baku yang dapat mengakibatkan dermatitis kontak. Namun secara teknis diakui bahwa alat pelindung diri tidak sempurna untuk melindungi tubuh, akan tetapi dapat mengurangi tingkat keparahan pada kecelakaan dan potensi dermatitis kontak yang terjadi.

Hasil penelitian Ola et al. ( 2018) menunjukkan bahwa terdapat perbedaan orang yang menggunakan APD dengan tidak terhadap kejadian dermatitis, dalam penelitian ini diketahui bahwa responden 
tidak memakai APD dan terjangkit penyakit dermatitis yaitu sebanyak 49,0\% dan responden tidak menggunakan alat pelindung diri serta tidak mengalami penyakit dermatitis yaitu sebanyak 51,0\%

Untuk menghindarkan pekerja kontak secara langsung dengan agen-agen fisik, kimia maupun biologi, maka penggunaaan alat pelindung diri sangat ditekankan. Hal ini sejalan dengan yang dikemukakan oleh Cahyawati \& Budiono (2011), bahwa tenaga kerja atau pekerja dalam bekerja yang tidak memakai alat pelindung diri maka kulit menjadi tidak terlindungi dan kulit akan lebih mudah terpapar oleh bahan iritan maupun alergen. Hasil penelitian Rahmatika et al. (2020) menemukan bahwa terdapat hubungan yang signifikan antara petani di Kabupaten Pesawawan Lampung yang mengalami Dermatitis dengan menggunakan APD secara tidak lengkap. Alat pelindung diri memiliki fungsi dalam memproteksi bagian tubuh pekerja serta dapat melindungi seluruh tubuh ataupun sebagian dari kemungkinan bahaya paparan dari luar di lingkungan kerja (Fielrantika \& Dhera, 2018). Kebersihan APD juga dapat mencegah keparahan kondisi kulit disebabkan kondisi lingkungan kerja yang lembab, sehingga dapat mencegah terjadinya dermatitis kontak. (Nugroho \& Sumini, 2015).

Personal hygiene dengan Gejala Dermatitis

\section{Kontak}

Berdasarkan pengolahan data dan hasil analisis data yang dilakukan oleh peneliti didapat nilai $\mathrm{p}=0,396(\mathrm{p}>0,05)$ yang berarti tidak ada hubungan antara personal hygiene terhadap gejala dermatitis kontak. Namun hasil analisis dengan menggunakan responden yang memiliki masa kera diatas 1 tahun menunjukkan bahwa terdapat perbedaan perilaku personal hygiene pekerja yang memiliki masa kerja lama dengan kejadian penyakit dermatitis. Pekerja yang memiliki masa kerja lama akan lebih berpengalaman menghindari terjadinya penyakit dermatitis dengan perilaku membersihkan diri dan pakaiannya. Penelitian yang dilakukan $\mathrm{Za}$ nia et al. (2017) menunjukkan bahwa terdapat hubungan personal hygiene nelayan dengan kejadian dermatitis di Kabupaten Kolaka. Dermatitis kontak terjadi karena kurangnya perhatian nelayan terhadap kebersihan diri terutama menjaga kebersihan pakaian kerja setelah pulang kerja. Kebanyakan dari pekerja ini kurang memperhatikan kebersihan pakaian. Sehingga kebersihan diri ini sangat berhubungan dengan kejadian dermatitis kontak pada nelayan. Sejalan dengan ini penelitian yang dilakukan oleh Sari et al. (2019) menunjukkan bahwa kejadian dermatitis pada para pemulung di Surakarta salah satunya diakibatkan karena personal higiene. Sebagian 
besar sampel yang diteliti (70\%) memiliki perilaku yang kurang baik dalam menjaga kebersihan dirinya.

Kegiatan membersihkan badan setelah melakukan proses pekerjaan dapat menghilangkan beberapa zat atau bakteri penyebab dermatitis yang menempel pada kulit ketika telah terjadi kontak dengan dengan bahan organik atau kimia.

Sebanyak 35 responden, 25 diantaranya melakukan personal hygiene baik dan sisanya tidak baik dalam personal hygiene yaitu sebanyak 10 responden. Dari 35 responden yang melakukan personal hygiene baik 13 diantaranya mengeluhkan adanya gejala dermatitis kontak dan 12 tidak ada gejala dermatitis, yang melakukan personal hygiene tidak baik 4 di antaranya mengeluhkan adanya gejala dermatitis kontak dan 6 tidak ada gejala dermatitis. Hal ini menunjukan ada hubungan yang signifikan antara personal hygiene dengan gejala dermatitis kontak. Kegiatan personal higyene yang dilakukan meliputi mencuci tangan, kaki, wajah, dan mengganti pakaian setelah pekerja selesai melakukan pekerjaan atau berkontak dengan bahan baku. Beberapa upaya yang dapat dilakukan dalam mencegah timbulnya penyakit dermatitis di lingkungan kerja adalah dengan modifikasi tempat kerja yang sesuai untuk mengurangi paparan agen penyebab (Al-Otaibi \& Alqahtani, 2015).

\section{KESIMPULAN}

Penelitian ini menemukan bahwa di peternakan ayam Pancur Batu Medan terdapat pekerja ternak ayam sebanyak 13 orang yang mengalami gejala dermatitis kontak. Penelitian ini juga menemukan bahwa ada hubungan antara personal hygiene pekerja dengan masa kerja di atas 1 tahun dengan timbulnya gejala dermatitis kontak pada pekerja. Tidak ada hubungan antara masa kerja, penggunaan APD dengan gejala dermatitis kontak pada pekerja ternak ayam. Penilitian ini diharapkan dapat memberikan kontribusi bagi para peneliti selanjutnya serta informasi bagi pemilik ternak dalam menambah pengetahuan dan keterampilan pentingnya menjaga higienitas dalam bekerja.

\section{SARAN}

Pekerja sebaiknya menjaga personal hygiene dengan baik agar tidak terjadi dermatitis/ mengurangi terjadinya dermatitis kontak. Pekerja harus menggunakan alat pelindung diri secara lengkap yaitu sarung tangan, baju lengan panjang, dan sepatu boot. Disamping itu pemilik ternak harus mengatur penggunaan alat pelindung diri secara tegas sehingga tidak ada lagi pekerja yang tidak menggunakan alat pelindung diri, pemilik ternak harus menyediakan air bersih agar pekerja dapat menjaga personal hygiene masing-masing. Dalam penelitian 
selanjutnya diharapkan peneliti meneliti variabel berbeda yang berhubungan dengan gejala dermatitis kontak guna memperkaya wawasan dan keilmuan di bidang kesehatan dan keselamatan kerja.

\section{DAFTAR PUSTAKA}

Al-Otaibi, S. T., \& Alqahtani, H. A. M. (2015). Management of contact dermatitis. Journal of Dermatology \& Dermatologic Surgery, 19(2), 86-91. https://doi.org/10.1016/ j.jdds.2015.01.001

Behroozy, A., \& Keegel, T. G. (2014). Wet -work exposure: a main risk factor for occupational hand dermatitis. Safety and health at work, 5(4), 175-180. https://doi.org/10.1016/ j.shaw.2014.08.001

Cahyawati, I. N., \& Budiono, I. (2011). Faktor yang berhubungan dengan kejadian dermatitis pada nelayan. KEMAS: Jurnal Kesehatan Masyarakat, 6(2). https:// doi.org/10.15294/kemas.v6i2.1766

Diepgen, T. L. (2012). Occupational skin diseases. JDDG: Journal der Deutschen Dermatologischen Gesellschaft, 10(5), 297-315. https://doi.org/10.1111/j.16100387.2012.07890.x

Djuanda, A., (2017). Ilmu Penyakit Kulit \& Kelamin. Badan Penerbit Fakultas Kedokteran Universitas Indonesia

Fielrantika, S., \& Dhera, A. (2017). Hubungan Karakteristik Pekerja, Kelengkapan Dan Higienitas Apd Dengan Kejadian Dermatitis Kontak (Studi Kasus Di Rumah Kompos Jambangan Surabaya). The Indonesian Journal of Occupational Safety and Health, 6(1), 16-26. http://dx.doi.org/10.20473/ijosh.v6i 1.2017.16-26

Indrawan, I. A., Suwondo, A., \& Lestantyo, D. (2014). Faktor-Faktor Yang Berhubungan Dengan Kejadian Dermatitis Kontak Iritan Pada Pekerja Bagian Premix Di PT. X Cirebon. Jurnal Kesehatan Masyarakat (e-Journal), 2(2), 110$118 . \quad$ Retrieved from https://ejournal3.undip.ac.id/in dex.php/jkm/article/view/6385

Jakasa, I., Thyssen, J. P., \& Kezic, S. (2018). The role of skin barrier in occupational contact dermatitis. Experimental Dermatology, 27(8), 909-914. https://doi.org/10.1111/exd.13704

Kalboussi, H., Kacem, I., Aroui, H., El Maalel, O., Maoua, M., Brahem, A., El Guedri, S., Chatti, S., Ghariani, N., \& Mrizak, N. (2019). Impact of Allergic Contact Dermatitis on the Quality of Life and Work Productivity. Dermatology Research and Practice, 2019. https://doi.org/10.1155/2019/379753 6

Kantor, R., \& Silverberg, J. I. (2017). Environmental risk factors and their role in the management of atopic dermatitis. Expert review of clinical immunology, 13(1), 15-26. https://doi.org/10.1080/1744666X.2 016.1212660

Kasemsarn, P., Bosco, J., \& Nixon, R. L. (2016). The role of the skin barrier in occupational skin diseases. Skin Barrier Function, 49, 135-143. https://doi.org/10.1159/000441589

Kementerian Pertanian. (2018). Statistik Peternakan dan Pemeliharaan Hewan. 
https://ditjenpkh.pertanian.go.id/userf iles/File/Buku_Statistik_2018__Final_ebook.pdf?time $=1543 \overline{2} 10844$ 103

Lau, M. Y. Z., Burgess, J. A., Nixon, R., Dharmage, S. C., \& Matheson, M. C. (2011). A review of the impact of occupational contact dermatitis on quality of life. Journal of Allergy, 2011. https://doi.org/10.1155/2011/964509

Marron, S. E., Cebrian-Rodriguez, J., Alcalde-Herrero, V. M., de Aranibar, F. G. L., \& Tomas-Aragones, L. (2020). Psychosocial Impact of Atopic Dermatitis in Adults: A Qualitative Study. Actas DermoSifiliográficas (English Edition), 111(6), 513-517. https://doi.org/10.1016/j.adengl.2019 .03 .030

Nawangsih, F. A., Nugrohowati, N., \& Harfiani, E. (2020, June). Factors Affecting the Occurrence of Suspected Contact Dermatitis in the Traditional Fishery Processing Area (PHPT) of Muara Angke. In IOP Conference Series: Earth and Environmental Science (Vol. 519, No. 1, p. 012027). IOP Publishing. https://iopscience.iop.org/article/10.1 088/1755-1315/519/1/012027/meta

Ningtiyas, A. F. (2013). Sarung Tangan Latex Sebagai Upaya Pencegahan Dermatitis kontak. KEMAS: Jurnal Kesehatan Masyarakat, 9(1), 92-99. https://doi.org/10.15294/kemas.v9i1. 2835

Nugroho, A. A., \& Sumini, S. (2015). Hubungan Perilaku Penggunaan Alat Pelindung Diri (APD) Pada Buruh Tani Dengan Kejadian Penyakit Kulit. Jurnal Ilmiah Permas: Jurnal Ilmiah STIKES Kendal, 5(2), 38-43. https://doi.org/10.32583/pskm.5.2.20
$15.38-43$

Nutten, S. (2015). Atopic dermatitis: global epidemiology and risk factors. Annals of nutrition and metabolism, 66(Suppl. 1), 8-16. https://doi.org/10.1159/000370220

Ola, C. M., Azwar, M., \& Ratnaningsih, M. (2019). Kejadian dermatitis pada masyarakat nelayan. Journal Health Community Empowerment, 2(1), 122-132.

Peiser, M., Tralau, T., Heidler, J., Api, A. M., Arts, J. H. E., Basketter, D. A., English, J., White, I. R., \& Johansen, J. D. (2012). Allergic contact dermatitis: epidemiology, molecular mechanisms, in vitro methods and regulatory aspects. Cellular and Molecular Life Sciences, 69(5), 763-781. https://doi.org/10.1007/s00018-0110846-8

Pollock, S. L., Stephen, C., Skuridina, N., \& Kosatsky, T. (2012). Raising chickens in city backyards: the public health role. Journal of community health, 37(3), 734-742. https://doi.org/10.1007/s10900-0119504-1

Pradaningrum, S., Lestantyo, D., \& Jayanti, S. (2018). Hubungan personal hygiene, lama kontak, dan masa kerja dengan gejala dermatitis kontak iritan pada pengrajin tahu Mrican Semarang. Jurnal Kesehatan Masyarakat (E-Journal), 6(4), 378-386. https://ejournal3.undip.ac.id/index.ph $\mathrm{p} / \mathrm{jkm} / \mathrm{article} / \mathrm{view} / 21442$

Qin, R., \& Lampel, H. P. (2015). Review of occupational contact dermatitis - top allergens, best avoidance measures. Current Treatment Options in Allergy, 2(4), 349-364. https://doi.org/10.1007/s40521-0150063-z 
Ramdan, I. M., Ilmiah, S. H., \& Firdaus, A. R. (2018). Occupational irritan contact dermatitis among shipyard workers in Samarinda, Indonesia. KEMAS: Jurnal Kesehatan Masyarakat, 14(2), 239-246. https://doi.org/10.15294/kemas.v14i 2.13417

Sari, N. K., Rahardjo, S. S., \& Widyaningsih, V. (2019). Factors associated with personal hygiene, use of personal protective equipment, and the risk of contact dermatitis among scavengers: A path analysis evidence from Surakarta, Central Java. Journal of Health Promotion and Behavior, 4(3), 198-211. https://doi.org/10.26911/thejhpb.201 9.04.03.05

Sharma, A., Mahajan, V. K., Mehta, K. S., Chauhan, P. S., Sharma, V., Sharma, A., Wadhwa, D., \& Chauhan, S. (2018). Pesticide contact dermatitis in agricultural workers of Himachal Pradesh (India). Contact dermatitis, 79(4), 213-217. https://doi.org/10.1111/cod.13049
Susilo, A. A. (2020). Potensi Usaha Ternak Itik Pedaging dalam Meningkatkan Pendapatan Masyarakat Desa Selokgondang. Iqtishodiyah: Jurnal Ekonomi dan Bisnis Islam, 6(2), 109133.

https://doi.org/10.36835/iqtishodiyah .v6i2.358

https://ejournal.inzah.ac.id/index.php /iqtishodiyah/article/view/358

Tsai, T. F., Rajagopalan, M., Chu, C. Y., Encarnacion, L., Gerber, R. A., Santos $\square$ Estrella, P., Llamado, L. J. Q., \& Tallman, A. M. (2019). Burden of atopic dermatitis in Asia. The Journal of dermatology, 46(10), 825-834. https://doi.org/10.1111/13468138.15048

Zania, E., \& Junaid, J. (2018). Faktor-faktor yang Berhubungan dengan Kejadian Dermatitis Kontak pada Nelayan di Kelurahan Induha Kecamatan Latambaga Kabupaten Kolaka Tahun 2017. (Jurnal Ilmiah Mahasiswa Kesehatan Masyarakat), 3(3). http://dx.doi.org/10.37887/jimkesma s.v3i3.5256 